\title{
Influence of Pretreatment with Constant and Changing Temperatures on Heat and Freezing Resistance in Gill-Epithelium of the Mussel Mytilus edulis
}

\author{
H.-W. Huppert and H. Laudien \\ Zoologisches Institut der Universität Kiel, Lehrstuhl für Zoophysiologie, OlshausenstraBe N41a, D-2300 Kiel 1, Federal \\ Republic of Germany
}

\begin{abstract}
We have investigated the influence of constant and changing temperatures (CT) and of different salinities on heat and cold resistance of the ciliary epithelium of the common mussel Mytilus edulis from different biotopes. Reasonable heat adaptation can only be obtained with mussels of the North and Baltic Seas in low salinity - not in high salinity. Re-adaptation to high and to low adaptation temperatures (AT) requires the same period of time; it is completed after $3 \mathrm{~d}$. Mussels were placed abruptly into water of different temperatures; initially this resulted in high standard deviations. The same response was obtained in CT in high salinities, but no heat adaptation was demonstrable. Periodic changes in temperature $\left(12 \mathrm{~h} 8^{\circ} \mathrm{C}, 12 \mathrm{~h} 20^{\circ} \mathrm{C}\right)$ result in increased heat resistance; a new level is reached after $3 \mathrm{~d}$; its value correlates with high AT. Standard deviations do not decrease. This was the same with $6 \mathrm{~h}$-periodic changes. Resistance to freezing correlates with constant AT. Abrupt single changes in a 12-h rhythm present a particular load, which initially leads to increased heat resistance and sensitivity to cold, and which shortens the life span of unfed individuals.
\end{abstract}

\section{INTRODUCTION}

Within the normal temperature range we must distinguish between a frequently existing capacity adaptation and effects due to stress, which, for instance, can be caused by rapid alterations of AT or by rhythmically changing temperatures (CT). Most animals are exposed to $\mathrm{CT}$ in their biotopes. The fact that animals can adapt to both constant and changing temperature regimes and that both regimes may induce different response patterns has been established by Kinne (1952, 1953, p. 190-194) for Gammarus duebeni. Randzio (1972) investigated the oxygen consumption of male cockroaches Blaberus craniifer. There was no capacity adaptation following constant temperature pretreatment. However, when the animals were transferred from constant AT into CT $\left(14^{\circ}-27^{\circ} \mathrm{C}\right)$, oxygen consumption increased the next day (CT acts as stressor), and then decreased to the standard value (stressor adaptation). Measurements were always taken at the same experimental temperature (ET). Cycling temperatures exert comparable effects (metabolism and activity) in Mytilus edulis. In environments with marked frequent fluctuations in temperature (e. g. outflow of cooling water from a power station), filtration rate and oxygen consumption are temperature-independent (Widdows, 1976). The fish Idus idus, which is very sensitive to stressors, also shows stressor adaptation after transfer from constant AT to CT (Braune and Gronow, 1975, cf. Künnemann and Precht, 1975; Laudien and Föh, 1975).

Also with extreme temperatures we must differentiate between resistance adaptation (heat or cold adaptation) and stress phenomena. Heat resistance of animals living in changing temperatures is often greater than in animals kept at an average constant temperature. This has been explained by the frequently observed temperature dependence of the adaptation process (greater increase in heat resistance during high day temperatures than resistance loss during lower temperatures at night), e. g. in wood-lice (Edney, 1964) and snails (Al-Habbib and Grainger, 1977). In Idotea balthica, the temperature coefficient for heat adaptation is 1 during the first $12 \mathrm{~h}$ following a change in acclimation temperature (Furch, 1972). Nevertheless, there was increased heat resistance after CT treatment. We have to take into consideration that within the normal temperature range harmful effects of a 
stress situation ('Belastungszustand') are removed by stressor adaptation ('Stressoranpassung'). An increase in resistance due to stress is always useful and can be interpreted as stressor adaptation.

Intertidal species are often exposed to periodical oscillations of temperature. For this reason we have investigated the resistance of the ciliary epithelium of Mytilus edulis L. to heat and freezing. Mussels from the North Sea are often exposed to great changes in temperature (solar radiation during low tide, cold water during high tide). Mussels of the Baltic Sea are subject to fewer temperature changes, since tides exert little effect.

According to Friedrich (1967), the ciliary epithelium of Mytilus edulis shows reasonable heat and cold adaptation (heat resistance and sensitivity to cold increase with rising AT). Heat shocks (10 min, $32^{\circ}-34^{\circ} \mathrm{C}$ ) increased the heat resistance $\left(\mathrm{ET} 36^{\circ} \mathrm{C}\right.$ ); this indicates hardening, as defined by Alexandrov (1977; see also Basedow, 1969; Theede, 1970). This problem will not be analysed further here. We have investigated whether the ciliary epithelium of $M$. edulis shows gains in resistance after pretreatment in appropriate temperatures (single, abrupt changes in temperature, CT), which differ from gains caused by normal adaptive processes, and which can be interpreted as stressor adaptation.

\section{MATERIALS AND METHODS}

Mytilus edulis L. from the Baltic Sea and from the North Sea, collected throughout the year (shell length $5-6 \mathrm{~cm}$ ), were used. Baltic Sea mussels were taken from a mussel bed at a depth of $1 \mathrm{~m}$ at the Falkenstein Beach, Kiel Bay, FRG. North Sea mussels were obtained from a mole in the Wadden Sea on the west coast of Schleswig-Holstein (Büsum, FRG). We took only mussels from medium depths, covered with water during high tide and for the same period of time exposed to air during low tide.

Transportation of the Baltic Sea mussels required about 20 min. We stored them in closed containers without risking oxygen starvation. During the $2 \mathrm{~h}$ it took to transport mussels from the North Sea, these were kept in open polyethylene containers covered with very little water. Vibration from the drive kept the water moving, thus we could assume that gas exchange was stimulated by water movement.

In the laboratory the shells were carefully cleaned of overgrowth. The mussels were kept in plastic beakers (height $8 \mathrm{~cm}$, diameter $6 \mathrm{~cm}$, each containing 6 individuals) suspended in 40-1 polyethylene containers. The beakers were perforated (hole diameter $1.5 \mathrm{~cm}$ ) so that the water could pass through easily. The mussels settled down with new byssus fibers shortly afterwards; most shells were slightly open. This behavior is considered normal (Theede, 1963) and can serve as indication that the animals were not severely injured. No food was provided.

The mussels were kept in $15 \%, 25 \%$ or $30 \% \mathrm{~S}$. The starting medium was water from Kiel Bay $(16 \%-18 \%$ S); this was diluted by adding tap water or concentrated by adding sea salt. Water lost through evaporation was automatically replaced with tap water. The water was continuously aerated, thus excluding oxygen deficiency which, according to Friedrich (1967) and Theede (1972), can modify their resistance to heat and cold.

Schlieper and Kowalski (1956) initiated increased ciliary activity in Mytilus edulis by adding protein breakdown products to the external medium. We cannot rule out the possibility that these substances also cause an increase in resistance. Since nitrogen excretion is very high in starving $M$. edulis (Bayne and Thompson, 1970), charcoal filters were used. Faeces, not picked up by the filters, were siphoned out at appropriate intervals. The water was changed every $14 \mathrm{~d}$.

All mussels were adjusted to a temperature of $8{ }^{\circ} \mathrm{C}$ for $14 \mathrm{~d}$. The purpose of this procedure was to level differences in resistance caused by previous temperature influences. Following this preliminary treatment, we exposed the mussels to temperatures of $14^{\circ}$ and

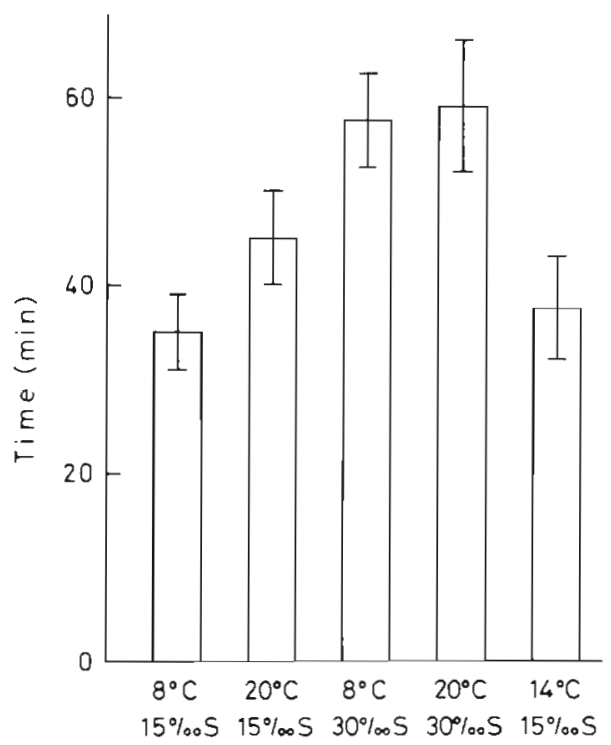

Fig. 1 Mytilus edulis (Baltic Sea). Heat resistance. Influence of adaptation temperature and salinity on heat resistance of gill epithelium. Adaptation to the combinations of temperature and salinity offered required $14 \mathrm{~d}$. Resistance was determined at an experimental temperature of $37^{\circ} \mathrm{C}$. Duration in $37^{\circ} \mathrm{C}$ until onset of cilia rigidity served as measure for heat resistance. All values based on 6 individuals. Vertical bars: standard deviation 
$20^{\circ} \mathrm{C}$, respectively, and started our tests after a 2 -week adjustment period to these constant temperatures. The photoperiod was always $12 \mathrm{~h}$ light, $12 \mathrm{~h}$ darkness.

In changing-temperature experiments $\left(12 \mathrm{~h} 8^{\circ} \mathrm{C}\right.$, $12 \mathrm{~h} 20^{\circ} \mathrm{C}$ ), the temperature was raised with heating elements and lowered with a cooling apparatus. The new temperature desired was reached within $1 \mathrm{~h}$.

\section{Determination of Resistance with Gill Cilia}

The duration of ciliary activity in constant high lethal temperatures has been used by many authors as a measure of heat resistance (e. g. Schlieper and Kowalski, 1956; Resthöft, 1961; Theede, 1965; Lagerspetz and Dubitscher, 1966; Friedrich, 1967; Senius, 1975, 1977). If heat resistance is not determined at a constant, lethal temperature, but under conditions of raising temperature, the temperature at which ciliary activity stops is used as measure of heat sensibility, depending on the rate of heating.

\section{Determination of Heat Resistance}

Median gills were taken out in sea water, cut into small strips and transferred to $50 \mathrm{ml}$ sea water in containers kept at $37^{\circ} \mathrm{C}$. At 5 -min intervals a strip was transferred to a Petri dish with sea water at $19^{\circ}-21^{\circ} \mathrm{C}$. The dish was kept on the stage of a stereomicroscope. A drop of graphite particle suspension was then pipetted on the gill piece and tested to see whether the ciliary epithelium was still able to transport the graphite particles (diameter 50-100 $\mu \mathrm{m}$ ).

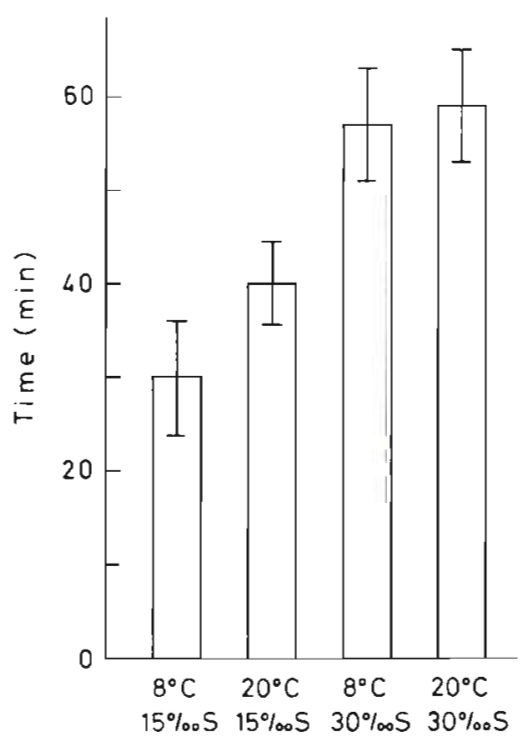

Fig. 2. Mytilus edulis (North Sea). Heat resistance. Influence of temperature-salinity combinations on heat resistance of gill epithelium. For further explanation see legend to Figure 1

\section{Determination of Cold Resistance}

Strips of median gills from 10 mussels were distributed evenly in 10 plastic beakers each containing $1 \mathrm{ml}$ sea water (each contained parts of gills from every mussel). The beakers were closed and suspended in a cold bath $\left(-10^{\circ} \mathrm{C}\right)$. Ice formation always occurred after 90 s. At appropriate intervals, we removed one beaker at a time and filled it with $100 \mathrm{ml}$ sea water $\left(20^{\circ} \mathrm{C}\right)$; $30 \mathrm{~s}$ later we could already determine whether graphite particles were still being transported. The time required for $50 \%$ of the cold-exposed gill strips to cease gill-transport activity served as criterion for cold resistance. The water used for storage, preparation and test had the same salinity.

\section{RESULTS}

\section{Heat Resistance after Long-Term Storage in Different Temperatures}

Effects of different adaptation temperatures (AT) on heat resistance of ciliary epithelium of Mytilus edulis are illustrated in Figures 1 and 2. Baltic Sea mussels with AT $20^{\circ} \mathrm{C}$ tolerate high, lethal temperatures longer than mussels from AT $8^{\circ}$ and $14{ }^{\circ} \mathrm{C}$. Mussels from middle AT reveal a resistance time between that for individuals adapted to warm and cold, respectively. Their resistance time does not, however, correspond to the arithmetic mean, but lies below it (cf. Senius, 1978). Thus the Baltic Sea mussels clearly show significant heat adaptation.

In biotope salinity, Mytilus edulis from the North Sea reveal higher resistance levels than those from the Baltic Sea (Fig. 2). Resistance time for mussels kept warm was approximately as high as that for mussels kept at low temperature. In order to determine whether the different heat-resistance limits of Baltic Sea and North Sea $M$. edulis result from genetic factors or from the different salinities of the North Sea (ca $30 \%$ S) and Baltic Sea (ca $15 \%$ S), Baltic Sea mussels were kept at $30 \% \mathrm{~S}$ and North Sea mussels at $15 \% \mathrm{~S}$. After transfer into the new saltinities both groups were left at $8^{\circ} \mathrm{C}$ for $10 \mathrm{~d}$ and half of the mussels were then transferred to $20^{\circ} \mathrm{C}$. Their resistance was determined 14 d later. Baltic mussels reveal a considerable increase in heat resistance after transfer to $30 \% \mathrm{~S}$ and, finally, reach the level of North Sea mussels (Fig. 1).

The heat resistance of North Sea mussels kept in $15 \% \mathrm{~S}$ drops significantly, attaining final values below the level of the Baltic Sea mussels from the same salinity (Fig. 2). Heat resistance depends on culture temperature only in low salinity. 


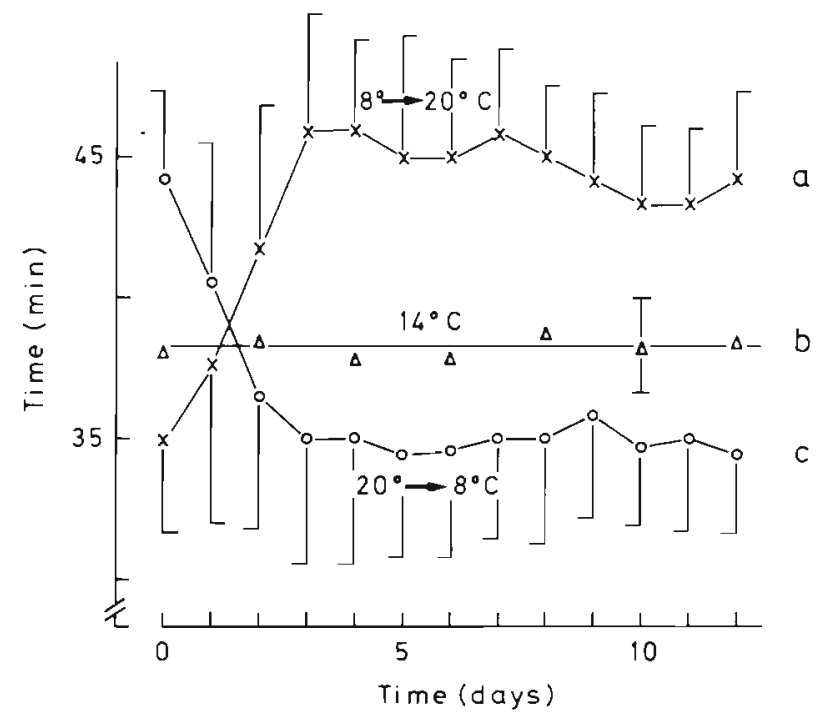

Fig. 3. Mytilus edulis (Baltic Sea). Heat resistance. Course of resistance change following abrupt transfer of mussels from AT $8^{\circ}$ to $20^{\circ} \mathrm{C}$ (a) and from AT $20^{\circ}$ to $8^{\circ} \mathrm{C}$ (c). 14-d adaptation prior to transfer into the new temperature. Adaptation and resistance were determined in $15 \% \mathrm{~S}$. (b): Values of AT for $14-{ }^{\circ} \mathrm{C}$ mussels. All values based on 10 individuals. Vertical bars: standard deviation (for clarity only one leg shown). For further explanation see legend to Figure 1

\section{Resistance Change after Single, Rapid Temperature Change}

\section{Baltic Sea Mussels}

Animals maintained at $15 \% \mathrm{~S}$ and at different temperatures show a dependence of heat resistance on maintenance temperature. The course of the changes in resistance to the point where a new, constant level is reached was investigated. The temperature change from $8^{\circ}$ to $20^{\circ} \mathrm{C}$ and from $20^{\circ}$ to $8^{\circ} \mathrm{C}$ was done by placing the animals into containers which already contained water of the new temperature, i. e., the change was abrupt. Here a stressor effect can be expected. Figure 3 (Curve a) shows a rapid increase of resistance values. The end value is already attained on the $3 \mathrm{rd} d$. It is noticeable that the values during the rising phase and the first values of the new level show large standard deviations. If the animals remain in the new temperature for several days, the standard deviations become smaller.

Curve c (Fig. 3) shows an almost reverse course of Curve a. A new resistance level is also already attained after $3 \mathrm{~d}$, but the time course is the same. Thus an influence of the direction of the temperature change on the speed of the adaptation process cannot be shown with Mytilus edulis. Senius (1975) achieved similar results. This does not hold true for many other species (cf. Precht, 1973), since with these animals re-adapta- tion takes place faster at a high temperature than at a low one

\section{North Sea Mussels}

Experiments with Mytilus edulis from the North Sea were carried out in $30 \% \mathrm{~S}$. All other conditions concurred with those in Figure 3. Figure 2 shows that mussels kept in $30 \% \mathrm{~S}$ display no resistance influenced by the culture temperatures $8^{\circ}$ or $20^{\circ} \mathrm{C}$. It cannot be ruled out, however, that abrupt temperature change may cause short-term resistance change.

Figure 4 reveals no deviation of resistance from its original value. However, standard deviations are again larger at the beginning ( 2 nd d) than later. A single temperature change, even if it takes place without any transition, exerts no influence on the heat resistance of North Sea mussels if these are kept in biotope salinity.

\section{Resistance Change after Transfer into Changing Temperatures}

Mytilus edulis responded to a switch from $8^{\circ}$ to $20^{\circ} \mathrm{C}$ and from $20^{\circ}$ to $8^{\circ} \mathrm{C}$, respectively (in low salinities), with a significant resistance change. The course of the changes was the same in both cases. In the biotope the mussels are often exposed to continuously changing temperature. To simulate these conditions we kept them at changing temperatures.

\section{Baltic Sea Mussels}

The mussels were kept at $8{ }^{\circ} \mathrm{C}$ for $14 \mathrm{~d}$ and then transferred to changing temperatures $\left(8^{\circ}\right.$ or $20^{\circ} \mathrm{C}$ in 12 h rhythm). Measurements were taken at 2 PM. The exact daily course was not examined. Figure 5 shows the course of resistance change.

A marked rise in heat resistance ends after $3 \mathrm{~d}$ at a new, constant level. The curves in Figures 3 and 5 thus show an almost identical course. However, values of mussels subjected to changing temperatures revealed considerably greater standard deviations. These are particularly large at the beginning and remain, after the new steady state value was reached, markedly larger than values of individuals kept at constant temperatures.

\section{North Sea Mussels}

With North Sea mussels, rhythmic temperature changes correspond more to natural tidal conditions. In order to avoid masking of temperature-dependent resistance changes by high salinity effects the mussels 


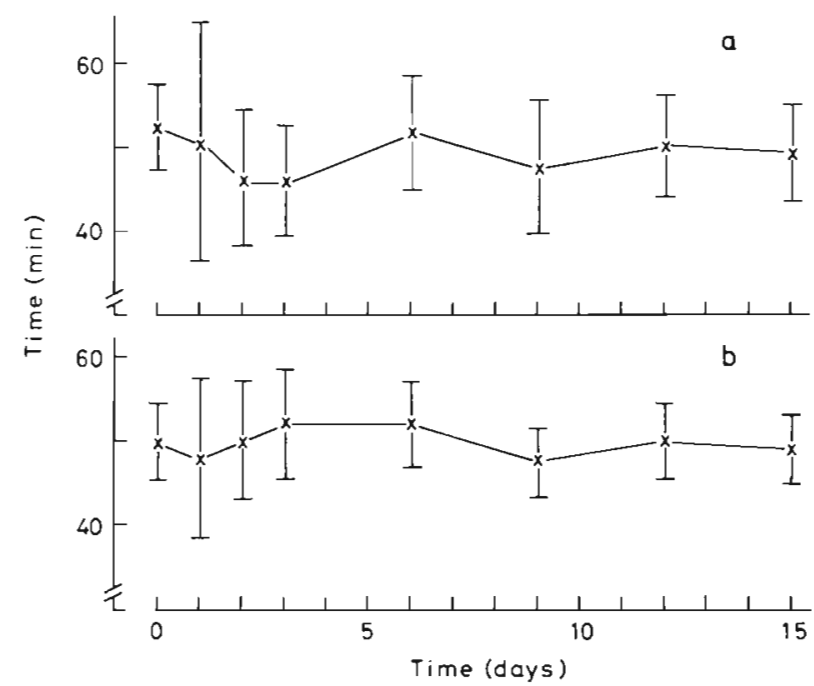

Fig. 4. Mytilus edulis (North Sea). Heat resistance. Course of resistance change following abrupt transfer from AT $8^{\circ}$ to $20^{\circ} \mathrm{C}$ (a) and from AT $20^{\circ}$ to $8^{\circ} \mathrm{C}(\mathrm{b})$. Adaptation and resistance were determined in $30 \% \mathrm{~S}$. For further explanation see legend to Figures 1 and 3

were exposed to $15 \% \mathrm{~S}$ for 2 weeks prior to the experiment.

In changing temperatures, the North Sea mussels exhibit the same resistance as their counterparts from the Baltic Sea. Resistance to heat increases quickly (Fig. 5) but stops after $3 \mathrm{~d}$. The curves differ only slightly at $8^{\circ} \mathrm{C}$. The lower value of North Sea mussels may be due to a load caused by low salinity (15\% S). There were no difference in the results after treatment with changing temperatures in a 6 -h rhythm.

\section{Freezing Resistance}

\section{Freezing Resistance Dependent on Salinity}

High salinity causes an increase in heat and freezing resistance. This also holds true for other species (cf. Kinne, 1954, 1971; Kähler, 1970; Remane and Schlieper, 1971; Murphy, 1976).

The dependence of freezing resistance on different salinities is shown in Figure 6.

From Figures 1 and 2 it is apparent that high salt concentrations not only cause an increase in resistance to high temperatures but also that AT cause a leveling of resistance differences. Since it cannot be ruled out that high salinities could also have a leveling effect with regard to freezing resistance, a salinity had to be selected in which the frozen gill strips could survive long enough to allow a sufficiently precise determination of freezing resistance. Thus for the following measurements we kept the mussels in $25 \% \mathrm{~S}$. Mytilus edulis does not reach its new level of resistance to low, critical temperatures until 4 to 6 weeks after the transfer to test salinities. Adjustment is faster in $20^{\circ} \mathrm{C}$ than in $8{ }^{\circ} \mathrm{C}$ (cf. Theede, 1972).

Dependence of Resistance to Freezing at Different AT

Gill strips from mussels exposed to different temperatures show a significant dependence of their freezing resistance on the AT. The periods employed were:

AT $8{ }^{\circ} \mathrm{C}: 40 \mathrm{~min}$ (at $-10^{\circ} \mathrm{C}$ up to $50 \%$ survived)

AT $14{ }^{\circ} \mathrm{C}: 26 \mathrm{~min}$

AT $20^{\circ} \mathrm{C}: \quad 19.6 \mathrm{~min}$

The $\mathrm{LD}_{50}$-time of AT $14-{ }^{\circ} \mathrm{C}$ mussels thus approximates that of AT $20{ }^{\circ} \mathrm{C}$ mussels.

Effect of Changing Temperature Pretreatment on Freezing Resistance

As has already been pointed out, a single or periodic temperature change can act as stressor in Mytilus edulis. This stressor causes an increase in resistance as a stress effect. Figure 7 shows the course of resistance change following transfer of $\mathrm{AT} 8-^{\circ} \mathrm{C}$ mussels (North

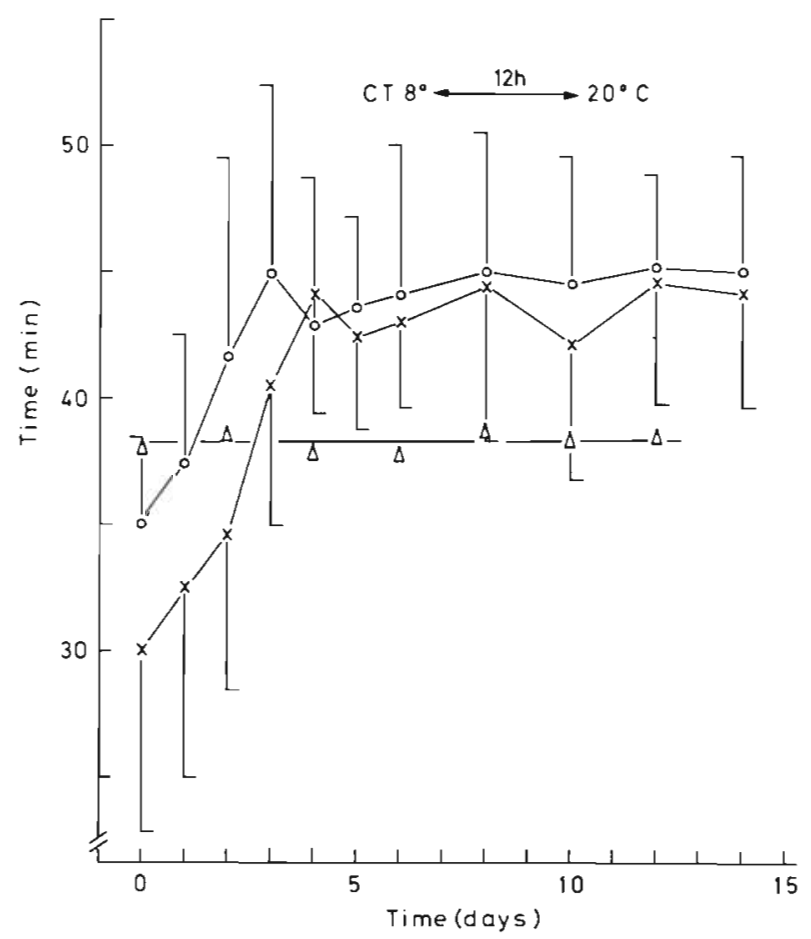

Fig. 5. Mytilus edulis ( $\mathrm{x}$ : North Sea; $\mathrm{O}$ and $\triangle$ : Baltic Sea). Heat resistance. Course of resistance change after transfer from AT $8^{\circ} \mathrm{C}$ to $\mathrm{CT} 20^{\circ}-8^{\circ} \mathrm{C}$ ( $\mathrm{x}$ and o: 12 -h change at $12 \mathrm{C}^{\circ} \mathrm{h}^{-1}$ ). $\triangle$ : AT $14-^{\circ} \mathrm{C}$ mussels. Adaptation and resistance were determined in $15 \% \mathrm{~S}$. Time of experiment: 2 PM. For further explanation see legend to Figure 1 


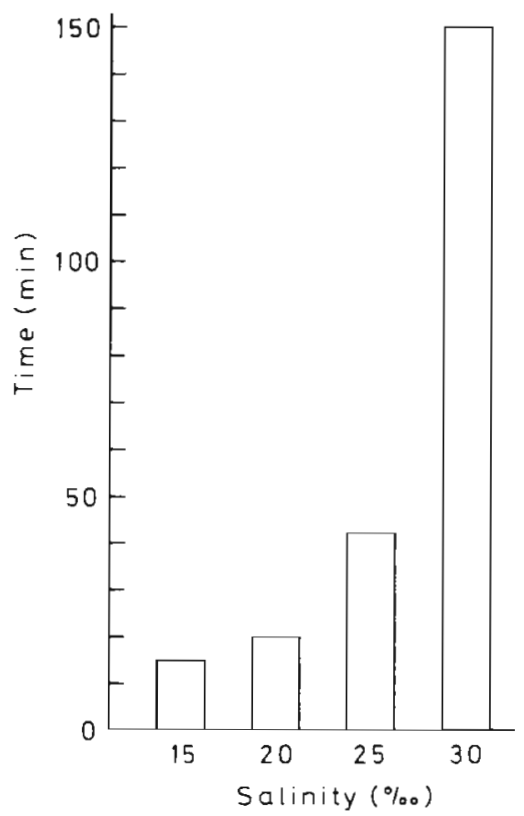

Fig. 6. Mytilus edulis (Baltic Sea). Freezing resistance. Survival time of gill epithelium at $-10^{\circ} \mathrm{C}$. AT: $8{ }^{\circ} \mathrm{C}$. Adaptation and resistance were determined in the salinities indicated

and Baltic Sea, respectively) into CT $8^{\circ}-20^{\circ} \mathrm{C}$. Resistance levels of gill tissue from $8-^{\circ} \mathrm{C}, 14-{ }^{\circ} \mathrm{C}$, and $20-{ }^{\circ} \mathrm{C}$ mussels were also recorded. Freezing resistance decreases immediately after starting the temperature change. After $3 d$, resistance reaches the level of AT $14-^{\circ} \mathrm{C}$ mussels; after $6 \mathrm{~d}$, that of AT $20-^{\circ} \mathrm{C}$ mussels. After $8 \mathrm{~d}$, the level reached remains constant. The stress effect presents itself here as a decrease in freezing resistance.

\section{Life Span of Mytilus edulis under Different Conditions in the Laboratory}

The following observation indicates that changing temperatures present a stress for Mytilus edulis. The time spans after which the mussels begin to die in laboratory experiments differ widely under different conditions. In $30 \% \mathrm{~S}$, these are at AT $8^{\circ} \mathrm{C}, 60 \mathrm{~d}$; at AT $20^{\circ} \mathrm{C}, 40 \mathrm{~d}$; at $\mathrm{CT} 8^{\circ}-20^{\circ} \mathrm{C}$ (changing every $12 \mathrm{~h}$ ), $25 \mathrm{~d}$; at $\mathrm{CT} 8^{\circ}-20^{\circ} \mathrm{C}$ (changing every $6 \mathrm{~h}$ ), $20 \mathrm{~d}$. Unfed mussels thus survive for a considerably shorter period in CT than in constant AT.

\section{DISCUSSION}

Resistance and capacity modifications caused by temperature have mostly been studied in animals (e. $\mathrm{g}$. fishes) from biotopes with only slow temperature changes. Here, modifications following AT-changes generally require several days to weeks. Among environmental factors, daylength, more than temperature, is responsible for seasonal changes in metabolism and resistance to extreme temperatures. How do animals behave which live under periodically fastchanging temperature conditions, i.e. in terrestrial or tidalzone habitats? Insects adapt to heat very quickly, i.e. within a few hours (for review see Precht, 1973, p. 436 ff.). Capacity adaptation apparently may proceed accordingly. Wieser (1977) discovered a relationship between enzyme activities (pyruvatkinase and lactate dehydrogenase) in foot muscle of Helix pomatia (collected and examined at night) and mean day temperature. High enzyme activity correlates to low day temperature, i.e. there is a compensatory effect.

How does this fit in with the findings on the resistance of cilia of Mytilus edulis reported here? Let us first discuss the more closely investigated heat resistance and heat adaptation, which requires in reduced salinities a few days (as in fishes). In some organisms, the mechanism of this adaptation is independent of temperature, e.g. in Zoothamnium hiketes (Vogel, 1966) or Idotea balthica (Furch, 1972); in others it is not (Precht, 1973). For Baltic Sea mussels exposed to low tidal amplitudes the long time required for adaptation seems understandable. However, how can this be of ecological significance in the tidal zone with quickly and drastically changing temperatures, e.g. in the North Sea? Here, such slow resistance adaptation to a tidal 6-h rhythm seems to be rather meaningless. We found that heat adaptation is lacking in high salinities.

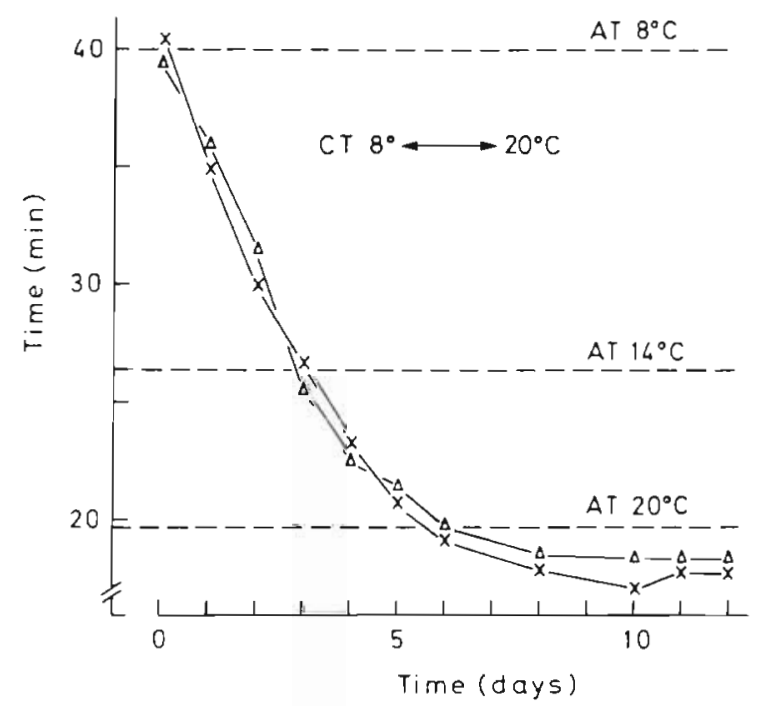

Fig. 7 Mytilus edulis ( $\triangle$ : North Sea, $x$ : Baltic Sea). Freezing resistance. Course of resistance change following transfer from AT $8^{\circ} \mathrm{C}$ to $\mathrm{CT} 8^{\circ}-20^{\circ} \mathrm{C}$. (12-h change at $12 \mathrm{C}^{\circ} \mathrm{h}^{-1}$; changes at $8 \mathrm{AM}$ and $8 \mathrm{PM}$, respectively). Adaptation and resistance determined in $25 \% \mathrm{~S}$. Time of experiment: $10 \mathrm{PM}$. Values for AT $8^{\circ}, 14^{\circ}$ and $20^{\circ} \mathrm{C}$ determined under identical conditions. All values based on 10 individuals 
In general a tidal rhythm is combined with high and not with low salinities. It seems, therefore, reasonable that cilia of mussels from the Baltic Sea adapt while those from the North Sea do not.

How can this be explained? Our experiments have shown that the different behavior of mussels from the North Sea and Baltic Sea is not due to racial differences. Is it possible that heat adaptation is blocked by high salinities? In the fish Idus idus fast temperature changes switch off capacity adaptation for a long time (Laudien and Föh, 1975), but this seems reasonable in regard to the biology of the animals only for those which live in biotopes with rather constant temperatures (Künnemann and Precht, 1979). Since heat resistance is a function of salinity, North Sea mussels are, due to a higher habitat salinity, more temperature resistant. Possibly, their high degree of resistance can hardly be increased. This possibility must be examined in more detail.

Especially the findings of Furch (1972) on Idotea balthica have shown that pretreatment with changing temperatures increases heat resistance, a phenomenon interpreted as stressor effect. Temperatures changing in a 12 -h rhythm $\left(8^{\circ}-20^{\circ} \mathrm{C}\right)$ cause in mussels from the North Sea and Baltic Sea an increase in heat resistance to the level of mussels which had been adapted to $20{ }^{\circ} \mathrm{C}$ for a very long period of time $(15 \% \mathrm{~S})$. This response cannot be produced by a larger effect of the warm period during pretreatment because the mechanism of reasonable heat adaptation is, as already mentioned, independent of temperature. Changing temperatures $\left(8^{\circ}-20^{\circ} \mathrm{C}\right)$ in a $6-\mathrm{h}$ rhythm exert a resistance-increasing effect on North Sea mussels from $30 \% \mathrm{~S}$, if they had been adapted to $20^{\circ} \mathrm{C}$ for a long period of time prior to the start of the change program. It seems problematical whether this increase in heat resistance due to a stressor can be interpreted as useful replacement for the lack of heat adaptation of North Sea mussels.

The freezing resistance of Mytilus edulis cilia has been examined in less detail. The experiments summarized in Figures 6 and 7 were conducted in December; exogen daylength influences were excluded. Mussels show a significant reasonable cold adaptation (25\% S). Freezing resistance increases at a constant $\mathrm{AT}$ with rising salinity. Changing temperatures $\left(8^{\circ}-20^{\circ} \mathrm{C}\right)$ in a 12 -h rhythm cause freezing resistance to drop to the level of the mussels long-term adapted to $20^{\circ} \mathrm{C}(25 \% \mathrm{~S})$. This is true for both, mussels from North and Baltic Seas.

\section{LITERATURE CITED}

Alexandrov, V. Y. (1977). Cells, molecules and temperature, Springer, Heidelberg
Al-Habbib, O. A. M., Grainger, J. N. R. (1977). The effect of constant and changing temperatures on the thermal resistance of Lymnaea peregra (Müller). J. Thermal Biol. 2: 191-195

Basedow, T (1969). Uber die Auswirkung von Temperaturschocks auf die Temperaturresistenz poikilothermer Wassertiere. Eine Untersuchung zum Problem der thermischen Schockanpassung bei Tieren. Int. Revue ges. Hy drobiol. 54: 765-789

Bashamohideen, M., Künnemann, H. (1979). Die Wirkung von Umweltbelastungen bei dem Fisch Idus idus L. (Cyprinidae). II. Der Einfluß von Temperaturänderungen auf ATP, ADP, AMP und Energieladung in Muskel und Gehirn. Zool. Anz. 202: 145-153

Bayne, B. L., Thompson, R. J. (1970). Some physiological consequences of keeping Mytilus edulis in the laboratory. Helgoländer wiss. Meeresunters. 20: 526-552

Braune, H.-J., Gronow, G. (1975). Zur Belastung von Idus idus L. (Teleostei) durch die Temperatur. Zool. Anz. 194: 22-34

Edney, E. B. (1964). Acclimation to temperature in terrestrial isopods. I. Lethal temperatures. Physiol. Zoöl. 37: 364-377

Friedrich, L. (1967). Experimentelle Untersuchungen zum Problem zellulärer nichtgenetischer Resistenzänderungen bei der Miesmuschel Mytilus edulis L. Kieler Meeresforsch 23: 105-126

Furch, K. (1972). Der Einfluß einer Vorbehandlung mit konstanten und wechselnden Temperaturen auf die Hitzeresistenz von Gammarus salinus und Idotea balthica. Mar. Biol. 15: 12-34

Gronow, G. (1974). Nukleinsäure- und Substratgehalte in der dorsalen Rumpfmuskulatur von Teleosteern während eines 'biologischen Stresses'. Mar. Biol. 24: 313-327

Heitlindemann, H. (1974). Gibt es eine biochemische Temperaturadaptation von wechselwarmen Tieren? Zool. Jb. (Anat., Ontogenie Tiere) 93: 77-108

Kähler, H. H. (1970). Über den Einfluß der Adaptationstemperatur und des Salzgehaltes auf die Hitze- und Gefrierresistenz von Enchytraeus albidus (Oligochaeta). Mar. Biol, 5: 315-324

Kinne, O. (1952). Experimentelle Untersuchungen zur Biologie, Okologie und Physiologie von Gammarus duebeni LILLJ. Ein Beitrag zur Kenntnis der Brackwasserorganismen. Ph. D. thesis, University of Kiel

Kinne, O. (1953). Zur Biologie und Physiologie von Gammarus duebeni LILLJ. II. Über die Häutungsfrequenz, ihre Abhängigkeit von Temperatur und Salzgehalt sowie über ihr Verhalten bei isoliert gehaltenen und amputierten Versuchstieren. Zool. Jb. (Physiol.) 64: 183-206

Kinne, O. (1954). Experimentelle Untersuchungen über den Einfluß des Salzgehaltes auf die Hitzeresistenz von Brackwassertieren. Zool. Anz. 152: 10-16

Kinne, O. (1971). Salinity: animals: invertebrates. In: Kinne, O. (ed.) Marine ecology, Vol. I, Environmental factors, Part 2. Wiley, London, pp. 821-995

Künnemann, H., Precht, H. (1975). Temperature as a stressor to poikilothermic animals. Zool. Anz. 194: 393-404

Künnemann, H., Behrens, C. (1978). Die Wirkung von Unweltbelastungen bei dem Fisch Idus idus L. (Cyprinidae). I. Der Einfluß von einem Wechsel der Temperatur und $\mathrm{NH}_{4} \mathrm{Cl}$ auf die Katalaseaktivität der Leber. Zool. Anz. 201: 380-386

Kunnemann, H., Precht, H. (1979). The influence of environmental temperature and salinity on animals. I. Poikilothermic animals and the normal range of temperature. II. Resistance of poikilothermic animals to heat and cold. Zool. Anz. 202: 154-171

Lagerspetz, K. Y. H., Dubitscher, I. (1966). Temperature accli- 
mation of the ciliary activity in the gills of Anodonta. Comp. Biochem. Physiol. 17: 665-671

Laudien, H., Föh, R. (1975). Über den Einfluß verschiedener Faktoren auf die Temperaturadaptionen bei Idus idus $\mathrm{L}$. (Pisces. Cyprinidae). Zool. Anz. 194: 376-386

Murphy, D. J. (1976). Metabolic and tissue solute changes associated with changes in the freezing tolerance of the bivalve mollusc Modiolus demissus. J. exp. Biol. 69: 1-12

Precht, H. (1973). Limiting temperatures of life functions. In: Precht, H., Christophersen, J., Hensel, H., Larcher, W. (eds) Temperature and Iife. Springer, Berlin, pp. 400-440

Randzio, G. (1972). Die Streßwirkung von Temperaturänderungen und Wechseltemperaturen, gemessen am Sauerstoffverbrauch von Blaberus craniffer (Blattodea). Zool. Anz. 189: 1-26

Remane, A., Schlieper, C. (1971). Biology of brackish water, Schweizerbart, Stuttgart

Resthöft, K. (1961). Untersuchungen zur zellulären osmotischen und thermischen Resistenz verschiedener Lamellibranchier der deutschen Küstengewässer. Kieler Meeresforsch. 17: 65-84

Schlieper, C., Kowalski, R. (1956). Über den Einfluß des Mediums auf die thermische und osmotische Resistenz des Kiemengewebes der Miesmuschel Mytilus edulis L. Kieler Meeresforsch. 12: 37-45

Senius, K. E. O. (1975). Thermal resistance acclimation of ciliary activity in the gills of fresh water mussels Anodonta anatina and Anodonta cygnea. Comp. Biochem. Physiol. 51C: $157-160$

Senius, K. E. O. (1977). Thermal resistance of the ciliary activity in the gills of the fresh water mussels Anodonta anatina. J. Thermal Biol. 2: 233-238

Senius, K. E. O. (1978). Control of the thermal resistance of ciliary activity in bivalve gills. Rep. Dep. Zool. (Turku) 7 : $1-35$

Theede, H. (1963). Experimentelle Untersuchungen über die Filtrationsleistung der Miesmuschel Mytilus edulis L. Kieler Meeresforsch. 1: 20-41

Theede, H. (1965). Vergleichende experimentelle Untersuchungen über die zelluläre Gefrierresistenz mariner Muscheln. Kieler Meeresforsch. 2: 153-166

Theede, H. (1972). Vergleichende ökologisch-physiologische Untersuchungen zur zellulären Kälteresistenz mariner Evertebraten. Mar. Biol. 15: 160-191

Vogel, W. (1966). Über die Hitze- und Kälteresistenz von Zoothamnium hiketes Precht (Ciliata, Peritricha). Z. wiss. Zool. 173: 344-378

Widdows, J. (1976). Physiological adaptation of Mytilus edulis to cyclic temperatures. J. comp. Physiol. 105: 115-128

Wieser, W. (1977). Slow, fast and medium fast responses of ectotherms to temperature changes: a new mechanism of metabolic compensation in Helix pomatia? J. Thermal Biol. 2: 197-202

This paper was presented by Dr. D. Siebers; it was accepted for printing on April 30, 1980 